\title{
Towards a Better Understanding of Public Resistance: Carbon Capture and Storage and the Power of the Independent-minded Citizen
}

\author{
Luise Beddies
}

\section{Introduction}

Projects like power plants, wind farms, electricity routes, airports or waste disposal sites go hand in hand with more or less significant interference with the balance of nature. This interference often causes resistance by individuals or groups, citizens' initiatives and environmental organizations, especially if the implementation or testing phase is supposed to take place right "next door". As a result of the increased citizens' involvement in environmental debates, research into public acceptance has become an important instrument for policy advice in recent years, not least because the past has shown that the public's opinion and attitude can have a crucial impact on the development of a technology. Projects or political decisions that fail to accommodate the broad public run the risk of facing strong resistance which can, in the end, interfere with or even prevent the implementation of the planned project.

One technical innovation that has caused a heated debate among policy makers, experts and citizens during the last years is the Carbon Capture and Storage (CCS) technology and its commercial use in power plant operation. The title CCS refers to the technique of capturing waste carbon dioxide $\left(\mathrm{CO}_{2}\right)$ from fossil fuel power plants, transporting it to a storage site via pipe lines and depositing it in an underground geological formation. The technique is supposed to prevent carbon dioxide, produced for instance in the steel and cement industry, from reaching the atmosphere and thereby contributing to global climate change. However, as CCS comes with many open questions and a lot of uncertainty in view of its technical, legal and economic feasibility and its potential for being a "bridging technology" between nuclear power and renewable energies, the technology was seen rather critically by the local public and politicians. In that, the CCS debate resembles several other infrastructural projects that had to struggle with public resistance and once it became clear that acceptance of technical innovations cannot be 
taken for granted anymore in a highly technological society, studies on the conditions and motives for acceptance or non-acceptance gained increasing importance for policy makers as well as academics in the field of social science or science and technology studies (STS).

But what does 'acceptance' actually mean? In most cases, acceptance is understood as the absence of resistance or sometimes even as the sympathetic tolerance of a certain technology or technological system by its direct or indirect users (Schäfer \& Keppler, 2013). However, this perspective is insufficient in the context of 'technology acceptance' for within the different phases of technological development and diffusion the acceptance of other actor groups (coming from the field of economics, politics, science or the public) is also relevant and sometimes even more important than the 'use"' acceptance (ibid.). Furthermore, for many current issues related to the transition from one technological path to another (e.g. from nuclear energy to renewable energies) acceptance is not only important in the sense of absence of resistance but also in the sense of active participation (ibid.).

As the CCS debate in Germany is rather new, only few scholars have studied the (lack of) public acceptance of this particular technology, whereas most of the existing studies mainly focused on the general perception of risks or potentials of the technology, while possible factors on opinion-making such as trust in experts, project initiators or political actors or communication strategies were mostly left out of the questioning of participants and the discussion of findings (Pietzner \& Schumann, 2012). One exception here is the paper Widerstand gegen Infrastrukturprojekte besser verstehen (2013) by Alexander Perez-Carmona. Investigating how motives of resistance against infrastructural projects and technical innovations can be understood more thoroughly from a social science perspective, Perez-Carmona names personal interest, risk aversion, (lack of) trust and finally (in)justice as the dominant motives of resistance and even though it mainly focuses on the German "Energiewende" and not on CCS in particular, his work and suggested categories have still built a useful foundation for the analysis of the CCS debate in this present thesis. As socio-scientific research on acceptance of technologies has shown, it is not primarily objective scientific knowledge that influences people's attitudes but also the subjective perception of the individual (e.g. Renn \& Rohrmann, 2000). In regard to concrete situations, voluntariness, controllability, fair distribution of risks and rewards and trust in the risk management are the deciding influences on an individual's perception and acceptance of technologies (Baker, 1990). Studying the full range of motives for nonacceptance is therefore crucial to understanding and gaining acceptance. By considering both the public's general perception of the risks and potentials of CCS (as a starting point) and the other factors that have influenced their opinion-making (for an in-depth analysis), 
using the motives proposed by Perez-Carmona as a guideline, the present work combines the focus points of the different studies published so far on public acceptance of CCS in Germany and provides a detailed study on the controversy about CCS in Germany and the role of public (non-)acceptance in this particular case. Within this rather comprehensive debate, the Vattenfall CCS demonstration project in Brandenburg served as a case study. It provided the opportunity to study a project that was not successful in the end because of a lack of public acceptance, especially in those areas that would have been directly affected by the project, which influenced and delayed the legislative procedure for a CCSlaw for Germany and left Vattenfall without a legal foundation for its demonstration and exploration project. What provoked this resistance by local citizens? Which circumstances and influences formed their opinion and what role did expert knowledge and scientific facts play in that respect? Finding answers to these questions is the main purpose of this paper.

\section{Carbon capture and storage in Germany: the long way to a CCS-law}

In June 2009, when the nuclear disaster of Fukushima had not yet taken place, the German Energiewende was still at an early stage. With their CCS Directive on geological storage of $\mathrm{CO}_{2}$ the European Union (EU) had created the first legal frame worldwide for the permanent storage and uniform permission, safety and environmental protection standards for $\mathrm{CO}_{2}$ storage sites, a legal frame which was supposed to get filled by the member states through a national law. Within the directive, two dates are of special significance: Until June 25th, 2011, the directive had to be transferred into national law and until the end of 2015 the demonstration projects were to start operating, in order to receive funding from the European Program for Recovery (EERP) and the EU Emissions Trading Scheme via the European Investment Bank. Six CCS-projects were selected for funding with 180 Million Euro each, including the project in Jänschwalde in Brandenburg, Germany (Kuckshinrichs \& Hake, 2012, pp.259-260).

In their coalition agreement, the German government, consisting of a federal coalition between the Christian Democratic Union (CDU)/Christian Social Union (CSU) and the liberal Free Democratic Party (FDP), had explained its position regarding climate protection, energy and environment. Stating that nuclear energy as a bridging technology would be irreplaceable for a transitional period of time and that the extension of life time for German power plants, obviously under observance of strict safety standards, would be unavoidable, it pointed out that it would promptly implement the European CCS 
Directive which regulated the capture, transport and storage of $\mathrm{CO}_{2}$ (Koalitionsvertrag, 2009, pp.28-29). However, keeping that promise proved to be harder than expected. Only one and a half years later, in April 2011, an agreement had been reached that allowed the government to implement the EU directives by passing a bill on the demonstration and application of the CCS technique which created a safe and reliable legal frame in its eyes (Mitschrift Pressekonferenz, 2011).

The reason the government delayed the bill was not least attributable to the fervid protest of some of the federal states. Especially the conservative-liberal governed Schleswig-Holstein was not willing to agree to a CCS-law if the federal state would not have the possibility to "exit" the regulation and to prohibit the testing in their state. This was due to massive local protest by citizens' initiatives against the $\mathrm{CO}_{2}$-storage in Schleswig-Holstein. The compromise that was finally found allowed the federal states substantial freedom of action in view of the CCS-testing, providing them with the possibility to designate (after expert consideration) areas in which $\mathrm{CO}_{2}$-storage would be permitted or prohibited. This regulation, in turn, was severely criticized by the federal state of Brandenburg, since it gave the federal states the option to completely back away from the CCS-testing - an opportunity that Schleswig-Holstein and Niedersachsen would most certainly take advantage of and a possibility that the red-red federal government, consisting of SPD (Social Democratic Party of Germany) and Die Linke (the Left Party) categorically rejected, stating that they were not willing to carry the burden of the testing alone, while everyone else shirked their responsibilities. "Brandenburg alone will not save the world climate" Prime Minister Matthias Platzeck contritely noted (Jung, 2011).

In general, the cabinet under Platzeck had a positive attitude towards CCS, not least because they feared the loss of jobs at the Swedish energy company Vattenfall, the biggest employer in the region. The company planned a big CCS demonstration power plant in Jänschwalde, Brandenburg, into which they wanted to invest 1,5 Billion Euro, hoping for an additional 180 Million Euro of funding by the EU, after the CCS project was selected first out of six in the EEPR ranking (Deutscher Bundestag, 2011).

\section{The case study: Vattenfall's demonstration project in Brandenburg}

Near the town Peitz in Brandenburg and not far from the Polish border, lies the biggest lignite-based power plant in Germany, Jänschwalde where the owner, the Swedish energy company Vattenfall, had plans to test and develop oxyfuel and post-combustion capture technologies. In order to find a permanent and safe storage site for the $\mathrm{CO}_{2}$, Vattenfall 
hoped to examine two geological structures in eastern Brandenburg that were assumed to be suitable. Both possible storage sites, Neutrebbin and Beeskow, are located more than $50 \mathrm{~km}$ away from the planned Demonstration Plant Jänschwalde in two rural regions near the Polish border and at a depth of approximately 1300m and even though both areas are only sparsely populated, they are home to around 30000 citizens (Vattenfall-Newsletter, 2010, p.12). So when Vattenfall went public with its plans to explore the structures of Neutrebbin and Beeskow in March 2009, it did not take the public long to react. While some locals were open towards the new technology and a dialogue about Vattenfall's plans, hoping that CCS could improve the image of the region and would create new jobs, others, including both "East and West Germans, the farmer and the artist" as a local citizen summarized, were highly critical and defensive from the beginning as they feared the (potentially dangerous and health threatening) consequences of the CCS procedure and shortly after Vattenfall had announced the possible storage sites, two citizens' initiatives against CCS were founded. In Beeskow, the initiative was called "Co2-Endlager stoppen", in Neutrebbin "CO2ntra Endlager". Even though they were founded independently of each other, there was a frequent exchange between them and over time a close cooperation was established.

With information events, demonstrations (including a fashion show to present the best anti-CCS protest outfit) and a regular picket in Letschin, the local citizens expressed their outrage and tried to get citizens as well as local politicians on board to stop Vattenfall from exploring their regions. On their websites, they presented several arguments for their protest: Once contaminated, drinking water would stay contaminated; the only real beneficiary of the project would be Vattenfall, who felt strengthened by a "renaissance" of lignite-based electricity production and would simply replace one risk technology by another under the cloak of climate protection; the risk of leakage would not be insurable and therefore unacceptable (Kritische Punkte, n.d.). The initiatives were not willing to accept this "high-risk technology", neither as a demonstration project nor as a potential export success as Federal Chancellor Angela Merkel was hoping (Bundesregierung, 2009) but promoted and demanded full concentration on further development and implementation of renewable energies (Hintergrund, n.d.).

But these arguments do not tell the whole story of why the local resistance in Brandenburg was that strong. Several other motives and factors that played a role for the non-acceptance will be presented and discussed in the following. 


\section{Citizens' initiatives declare war on Vattenfall - Motives}

\section{for resistance}

\section{Personal Interest}

Considering that the strongest resistance against CCS in Brandenburg came from the local citizens of Beeskow and Neutrebbin, it seems reasonable to assume that personal interest played a certain role for the non-acceptance of the planned demonstration project. Many locals felt that their lives and properties would be directly affected by a CCS demonstration project, threatening their physical and financial well-being. Like Sylvia Wadewitz, who had recently invested in real estate in Neutrebbin, they were not only afraid of potential health risks but also of a loss of value of their properties, for who would want to spend money for a house standing on top of a $\mathrm{CO}_{2}$ storage site (Brzoska, 2009)? The locals were convinced that a final storage site would ruin their landscape. Citizens would eventually leave and with them potential customers and the infrastructure, making all previous investments into the regions of Beeskow and Neutrebbin a waste of time and money (Fischer, 2010).

Yet, personal interest did not only play a role for the resistance itself, it is also important regarding the endurance and efficiency of the resistance in the potential storage site areas. The direct involvement was a powerful incentive for the local citizens' initiatives to deal with the topic technically, politically, legally and economically, to be informed in the best possible way and to become self-declared experts on the project and be able to face Vattenfall and politicians with a wide range of informed arguments against the project. As Ulf Stumpe, spokesperson of the initiative in Neutrebbin explained: It is highly important to be informed, via the internet, experts' literature or publications of the Intergovernmental Panel on Climate Change (IPCC) and other environmental institutions. Instead of being experienced as emotional, irrational protesters by authorities, they wanted to present well-founded arguments. Pointing out that they were by no means anti-science, he stressed that some of them, including himself as a veterinarian, even came from a "scientific background" themselves and that it was therefore even more important to them, that there was enough (scientific) knowledge about CCS before the actual demonstration of the technology would start (Schramm, 2010). As local citizens, they saw their existence literally hanging on a "burning fuse", experiencing CCS as a threat to their homes, their lives, their future and the safety of their children and grandchildren growing up in the area (Fischer, 2010). Because of this strong identification with the problem, as they assumed that CCS could be harmful to them or to future generations, it is then no surprise that the people affected were willing to continue protesting over a long period of 
time, not accepting any compromises, until their arguments would be taken seriously and recognized as an important factor in the dialogue, so that no one could be in the position to claim that he knew nothing about it afterwards (Schröder, 2010).

However, even though the idea of personal interest and affectedness is clearly an important piece of the puzzle when it comes to identifying the motives for resistance, it would be too easy to reduce people's motives to pure self-interest and label them egoists because they are concerned about what is happening beneath their feet. Instead, a closer look should be taken at their relation to and their assessment of risk as another important influence on their perception of CCS.

\section{Risk aversion}

Most people today seem naturally risk-averse. Complex insurance systems exist for all kinds of imaginable accidents and potential risks which explains peoples resistance towards new technologies that are categorized and experienced as "risky" or dangerous. Research conducted in the field of risk assessment and communication by Hance, Chess \& Sandman (1988) regarding the discrepancy between the supposedly objective risk assessment by risk experts and the supposedly subjective risk assessment of lay people brought two main findings. The first was that citizens had a much more complex understanding of risk than the experts and also than the experts expected them to have. They were not simply interested in the question whether the probability of death that is connected two technical solutions in case of an accident is smaller than that connected to everyday activities, as it was often suggested by experts. Instead, the citizens were interested in whether the risk was taken voluntarily or was something they were expected to cope with it, whether the risk could be controlled or was beyond their control or wether they were already familiar to the risk and whether the risks were natural or man-made.

CCS was experienced as especially risky by local citizens as it was an uncontrollable risk they would be exposed to by the authorities, without giving their consent, making them nothing more than Vattenfall's guinea pigs as Frank Steffen, mayor of Beeskow, termed it (Seidler, 2010). Other than driving a car, where the risks could be accepted in view of the advantages (getting from one point to another quickly etc.), the risk of an untested technology like CCS that came with seemingly no advantages for the local citizens, could not be accepted by them on reasonable grounds. In their eyes, CCS was a technology which had no future and the demonstration project was pure "madness" as the people responsible would deliberately accept to endanger life and limb of the local population (Fischer, 2010). Also, there was no chance of reducing the risk by being especially careful and if a leakage appeared, it would be out of the citizen's control. As the local population 
they would be affected by the consequences, not Vattenfall and it would therefore be only reasonable to reject not only the commercial use but also the planned demonstration project that would represent an unnecessary man made risk, for, so they argued, what good is technological edge and export potential, if the safety of the population is at stake (Schröder, 2010; Über uns, n.d.)?

Even though these points show that the assumption that citizens would have a false or too subjective perception of risk is inadequate, they also lead to a second main finding of Hance, Chess \& Sandman: This constructed discrepancy between objective (right) and subjective (wrong) risk assessment, that is presupposed by experts still gives proponents of certain technologies the rhetorical means to present protesting citizens as "irrational", a phenomenon that is rarely expressed openly because of political correctness but is still present in many political acceptance debates (1988; Baker, 1990). A phenomenon that the citizens' initiatives in Brandenburg also seemed to have been aware of as they were actively informing themselves about CCS to present well founded arguments against the technology instead of shouting random slogans, to make clear that the reasons for their protest were not just "diffuse fears of hysterical people" but concrete questions, concerning possible geological risks and problems that had not yet been answered sufficiently by politics and economy (Schröder, 2010).

However, that Vattenfall could not convince the opponents of the potential and necessity of their project had yet another reason besides a strong risk perception of the local population and that was trust or rather the lack of it in this particular case.

\section{(Lack of) Trust}

In a situation where the population had a strong risk perception (and aversion) and was therefore already rather critical of the CCS project, it was even more important for Vattenfall (as the project developer) and politicians (as decision makers), to make sure that their technical competence was not doubted and that they stayed trustworthy. For Vattenfall, this was however easier said than done, as the company had a bad reputation from the beginning of the debate.

When the Swedish energy supplier first came to Germany in the 1990s, he was welcomed with open arms even by the more alternative scene. It was hoped that Vattenfall would bring down some of the old structures in the power generation sector and promote the nuclear phase-out. But the euphoria was soon over. Today, CCS is just one of the many disputes Vattenfall is involved in, its reputation as an environmental energy company is crumbling and it seems that whatever project it tackles, there are always some citizens, associations and politicians that try to stop it (Sorge, 2011). The damaged "green" 
image of the company and the bad press led to a crucial loss of credibility that resulted in mistrust and suspiciousness towards the company in general and the information that was provided by them for the public in particular. And even though Vattenfall stated that its words and actions should not contradict each other, it had trouble adhering to this ideal in practice. In one of its monthly information brochures Vattenfall stated that it would fully understand the concerns people had regarding CCS as to most people it was a totally unknown concept with high scientific, technical and political complexity and that it would welcome their doubts and uncertainties, for the citizens would have the right to ventilate their concerns and to perceive proper answers to all the questions they had regarding CCS (Vattenfall-Newsletter, 2009). However, after being asked by the producer of the CCS documentary Energieland why he thinks local citizens would feel threatened by the company's project plans, Dr. Wolfgang Roland, Manager of Vattenfall Europe Carbon Storage $\mathrm{GmbH} \&$ Co. KG had to think for quite a long time until he finally answered that this was a good question indeed but that he could not give an answer to it as he had never really thought about it before (Ickert, 2010). Obviously, this did not back up the claim that Vattenfall cared about the concerns of the citizens but instead underlined the impression of the citizens' initiatives that Vattenfall did not care about their wishes. "We don't expect anything from anyone anymore", is how the initiative in Neutrebbin summarizes the general feeling. "We gain our strength from self-confidence but also from the confrontation with the federal government and the energy company as well as the sympathies we get from the citizens" (Fischer, 2010) It is no wonder that in such a situation even the best public relations strategy proves to be rather fruitless. Better would be to bring independent organizations or individuals on board who are experts in the field and can give an unbiased, rational recommendation.

Yet even these (supposedly) independent actors could not help to convince the public this time. One of the reasons was that Vattenfall's was not the only reputation that had suffered. The experts and their expertise too had a difficult standing in the debate. Not having enough information to make an informed decision about whether or not CCS was a safe and promising technology, when everyone (politicians, the public and Vattenfall) was demanding clear facts on which to build their decisions, opinions or campaigns, is certainly not a comfortable situation to be in. As Reinhard Hüttl, member of the "Ethikkommision für eine sichere Energieversorgung" stated, experts themselves do not necessarily aim to use science to create certainty. Instead, Hüttl believes that it is the job of the scientist to constantly challenge knowledge. By that he can secure the existing and generate new knowledge. That is, at least for Hüttl, the driving idea behind science. Politicians and the public are asking for facts and certainty but in the CCS debate the situation is far from 
clear at the moment. As in many other cases, politicians as well as the public are forced to form an opinion and to make decisions based on the best information available but on an uncertain base of knowledge (Grefe \& Schnabel, 2011).

\section{Feeling of injustice}

Closely related to the motive of trust, yet a separate category is that of justice or rather injustice/unfairness. Being chosen as a potential exploration area, citizens asked the question: Why here, why us? Why should we "swallow the risk pill" (Schröder, 2010)? What is important here in view of public acceptance are not so much geological and scientific facts (e.g. why the region would be suitable for testing) but that citizens felt that they and their protests were not taken seriously enough. When the government presented the planned bill that allowed federal states to prohibit CCS on their land under certain conditions (the so called "Länderklausel"), they strongly rejected it not only because they thought it would not be fair to them to carry the whole burden of the technology and to become the " $\mathrm{CO}_{2}$ Klo", the CO2 toilet, for Germany (Schröder, 2010), but especially because they understood the "Länderklausel" as a reaction to heavy local protest in Schleswig-Holstein and as a sign that the protest in Schleswig Holstein was taken more seriously by the government than their protest in Brandenburg (Bund plant CCS-Gesetz im Miniaturformat, 2010). This (in their eyes) unfair treatment and the feeling that they were not taken seriously enough to be taken into account during the legislative procedure, making them feel like "secondclass citizens" only strengthened their resentment and made it even more difficult for authorities to earn their trust and acceptance.

\section{The role of communication}

While the four categories personal interest, risk aversion, trust and justice or rather the discussed motives of resistance that fall into these categories all illustrate aspects of the citizens' perception of the relationship between themselves and the CCS technology (which is then closely related to their attitude towards the CCS project), studying the role of communication, i.e. the way information was made available and how it was perceived, provides additional and crucial insight into why Vattenfall was not able to earn the acceptance of local citizens and had to cancel the project in 2011.

In times of television, internet, electronic newspapers and other media, people have an overwhelming amount of information at their disposal. This information is used on a daily basis to gain an understanding of the world, to form opinions and make decisions. A selection of the total amount of information available is made, attention being paid to the information that is expected to be valuable (te Morse, 2009, p. 1). With familiar topics 
it is comparatively easy for people to evaluate the information that is accessible as they can make use of their background knowledge to judge the quality of the information. But what about complex issues that are unfamiliar? What happens when people cannot rely on existing background knowledge to judge?

CCS was such a complex, unknown issue to most people in Beeskow and Neutrebbin and therefore many lacked the necessary background knowledge to make an informed judgment. They were, at least to a certain degree, depending on the information that was provided to them by Vattenfall and independent experts to form an opinion about the CCS technology in general and the planned demonstration project in Brandenburg in particular and it was clearly in Vattenfall's interest to open a dialogue during which they could present the necessity and advantages of their project to the locals without imposing it on them. To build an open and trusting dialogue with the public, comprehensive scientific communication was essential, meaning that the relevant information on technical and scientific work and questions relating to the project not only needed to be provided to the public but also communicated clearly and understandably to them. The challenge of this "translation" of knowledge is that the information should not be trivialized or played down, regarding for instance open questions about possible risks. If those responsible succeed here and can explain and justify the necessity of their plans they can gain trust and acceptance. Yet, not only is the communication of information as such important, furthermore it is important that the dialogue with the public happens on equal terms. This implies that the initiators show an interest in the concerns and arguments of the citizens, that they admit possible research deficits and inform about the next possible steps. It is also crucial that apart from the technical and scientific aspects also societal and ethical challenges are faced. This means dealing with questions like: Which definition of safety is the discussion based on? How does the risk perception of the experts and the public differ? How should we deal with uncertainty and insecurity? Investigating these questions is an important basis for a process that is experienced as fair and appropriate by the public (König, 2013).

So what went wrong in view of communication in the Vattenfall case? How can the public's apparent dissatisfaction with the actual information provided be explained? In part it seems to lie in the distrust in the government to make the right decisions and in the dissatisfaction of being left out of most of the decision making process. Explaining why they chose "Wutbürger" (enraged citizen) to be German word of the year 2010, the Association for the German Language stated that this neologism had been used by numerous newspapers and television stations to reflect a public outrage at the fact that final political decisions were made without having included them. The word documented 
the public's strong need to have a say in socially and politically relevant projects that goes beyond their right to vote (Gesellschaft für Deutsche Sprache, 2010)

However, the main problem in view of the dissatisfaction with the provided information appeared to be Vattenfall. Addressing the controversy among local citizens in one of their information brochures, the company states: “From Vattenfall's side, we must continue to provide people in the local areas with solid, useful information so that they have an accurate picture of the situation at hand. This also entails sifting through all the myths in order to reach the hard core of useful information" (Bridging to the Future, 2010, pp.10-11). To this purpose, Vattenfall began a series of public events including lectures and expert presentations, "town hall" meetings, exhibitions, pilot plant tours or school visits where further information on the project was presented and citizens could ask questions. Apart from those events, Vattenfall opened an information office at Beeskow in July 2009 that was open several days a week, providing information on global warming, $\mathrm{CO}_{2}$ in general and CCS in particular. Also, a comprehensive website was created, including information in form of documentary films and animations, graphics and general articles. In addition, a regularly updated brochure called "Bridging to the Future" that answered frequently asked questions about CCS and the project was available for download and a free telephone hotline was offered. However, despite their efforts, Vattenfall still did not succeed in convincing the local citizens of the importance and advantages of their project. Why? Perhaps because it is not so much the issue or information itself that matters but rather the way this information is presented to the people?

To gain understanding of a complex issue such as CCS, people need to be informed. This involves providing them with factual, balanced information about the technology, its benefits as well as potential risks. In the best case scenario such information lets the established facts speak for themselves and gives people the opportunity to come to their own conclusions about the technology (ter Mors, p.4). However it was exactly this "balance" in information, that was doubted by the local citizens, criticizing Vattenfall for having a "deaf ear" when it came to the contra-CCS side and potential risks and uncertain consequences of the technology (Knaupp, 2010). Looking at the information provided by Vattenfall, they saw something very different from what Vattenfall hoped to provide. To make this more clear, the terms "informative communication" and "persuasive communication" are helpful. While the first refers to communication that aims to create awareness and deeper understanding of the issue in question, enabling people to form an informed opinion, the latter describes means of communication that aim to persuade people that a certain opinion is the right one (ter Mors, 2009, p.4). Even though Vattenfall provided a huge amount of information on CCS, information that was presented as 
informative, the public perceived it as persuasive information, accusing Vattenfall of providing one-sided information that was trivialized and based on studies that could easily be refuted by other expert reports (Knaupp, 2010; Die Vattenfalle, n.d.). Keeping this in mind, it is not surprising that Vattenfall's aim of inducing public acceptance of CCS by informing them extensively backfired. Persuasive campaigns are not likely to fulfill the information needs of affected citizens who expect them to contain one-sided information in favor of the company's plans and can even be considered unethical in cases like CCS, given the potential risks of the technology for those living next to storage sites (ter Mors, 2009, p.4).

Nevertheless, there is another factor that made it very difficult for Vattenfall and any other person or group in favor of the technology to provide the citizens with information that they considered valuable and that is the power of association. As mentioned earlier, we try to form an opinion about something by scanning our mind and memory for useful information or experiences that we have made. Being aware of this natural and often unconscious process, it can quite easily be manipulated by intentionally using specific terms and symbols that are believed to create certain associations in peoples' minds. In the case of Vattenfall, these associations played a major role in view of the acceptance or rather non-acceptance of the public as it was crucial for the forming of the public opinion whether CCS was associated with nuclear waste or climate protection strategies (Renn, 2011). Implying that they had learned from the debacle over nuclear waste disposal sites, the citizens' initiatives deliberately chose to take over the symbols of the anti-nuclear movement: Big wooden yellow X-crosses, standing for the "Day X", were positioned on properties in Beeskow and Neutrebbin. The term was originally used by protestors during the anti-nuclear movement to refer to the day the cask for storage and transport of radioactive material would arrive and was transferred into the CCS context by the initiatives in Brandenburg with respect to the day Vattenfall's machines to explore the region would arrive. Consequently, when talking about CCS, they chose their terms carefully by adopting the term of final disposal site ("Endlager"), until then mostly used in the anti-nuclear debate (Kreuze warnen vor Kohlendioxid-Risiko, 2010). This choice of symbols and terms obviously had a major influence on the perception of CCS, provoking people to consciously or unconsciously transfer their fears related to nuclear-waste disposal to the underground storage of $\mathrm{CO}_{2}$. 


\section{Conclusion}

Returning to the main questions asked in the beginning, what provoked the local citizens' strong and enduring resistance? Which factors influenced their opinion-forming process, which motives, perceptions and feelings, made them protest over such a long time and without accepting any compromises and which circumstances made it so difficult or rather impossible for Vattenfall to change their mind and win them over?

Looking at the wide range of motives and circumstances discussed above that played a role for local resistance during the CCS debate in Brandenburg, it is obviously not sufficient to explain resistance simply with the NIMBY phenomenon ("Not in my backyard") and the egoism of local citizens, with the irrationality of the opponent who has an inadequate, emotional and subjective perception of risk or to see the main problem in a mere misunderstanding (as it was implied by Vattenfall). This one-sided explanation of public resistance would be problematic as it disregards the complexity of motives for public resistance. Apart from personal interest, risk aversion and the citizens' perception of risks play an important role; as well as a lack of trust, the feeling of being unfairly treated and receiving one-sided information or rather failed communication strategy.

Of course, these five main motives for resistance cannot be seen separately. The first four motives, personal interest, a general and particular risk aversion and (lack of) trust and the feeling of being unfairly treated, are closely connected. Regarding the overarching motives of risk aversion and mistrust it was mostly dealt with negative expectations for the future concerning health and financial well-being of the individual and his or her family. The difference then lies in the fact that regarding risk aversion, the main concern is the potentially negative consequence of a technical "solution" (CCS as a climate protection strategy), like the leakage of a $\mathrm{CO}_{2}$ underground storage site and the contamination of ground water. A lack of trust however is connected to the future behavior of particular people; it is about the expected behavior of those who are commissioned to give recommendations (experts) and make decisions (politicians) and those who are assigned to implement these decisions (Vattenfall). The feeling of being unfairly treated is, however, closely related to personal interests and to the questions: Why here, why now, why us? Why is someone else's voice, someone else's concern, someone else's life and property taken more seriously?

Communication is at the same time a motive for the citizens to resist, as a tool for organizing effective resistance. As the communication strategy of Vattenfall (providing a huge amount and a wide range of information in all kinds of media formats) could not fulfill the purpose of informing the people and gave them the feeling of being persuaded by one-sided information (playing with terms and symbols to provoke influential 
associations). The last point has also shown that it is not so much the information itself that plays a role for acceptance or a lack of information, but the way it is translated and presented. This also applies to scientific knowledge and expertise and provides insights into the role expert knowledge and scientific facts play in the debate and for forming and justifying local resistance. While science and expertise were generally highly valued in view of making a founded argument by both opponents and supporters, the value that was assigned to the knowledge and facts depended on how and by whom it was used to make a claim. Both sides stated that they would use expert's reports and recommendations to form their opinion and legitimize their position and actions and especially the initiatives used it deliberately to be perceived as rational actors in the debate who could meet Vattenfall at eye-level in the discussion. However, instead of being the main influence during the formation, legitimation and presentation of citizens' opinion and resistance to CCS (which would have been a reasonable assumption considering the scientification of western society) it seems that factors like a general and particular risk aversion, the bad reputation of Vattenfall and the problems of communication appeared to be a much stronger incentive for resistance.

Altogether, the case study of the Vattenfall project has confirmed what acceptance research has claimed: Acceptance research today, as a barometer of public opinion on the perceived speed and evaluation of technical change, has an important empirical service function for the social theoretical interpretation of modernity. Instead of being a means of manipulating the locals' opinion, it should be an opportunity to study public (non-)acceptance as part of a bigger picture, namely current and future environmental controversies. In that respect there are three aspects to consider.

First, conflicts provoke responses which provoke change. They can lead to real consensus, creative compromises and in the end a better way to approach a certain goal as was the case in the anti-nuclear movement, which resulted in a change of the energy system and the development and increased use of renewable energies. Whether this succeeds, whether the conflict leads to a change for the better depends primarily on people, groups and individuals and their competence to listen, to communicate, to mediate and only to a lesser extent on the plans or projects themselves. In the case of the CCS controversy in Brandenburg, public resistance led to the failure of Vattenfall's planned demonstration project. Whether this is good or not and if so for whom remains to be seen as well as the consequences the failure will have for the future of CCS in Germany and the further development and use of renewable energies.

Second, the role of science and scientific knowledge or rather the provision of this knowledge needs to change and it already does. It is not about expert's opinion against 
expert's opinion or the fact that scientific "facts" can be interpreted very differently for different purposes even though this game is still played in many public debates, including that surrounding CCS. Science and expertise should serve as a mere tool in politics and public discourse. Instead, the role of science should be to question existing knowledge and to develop new ways of thinking. This implies that experts should not (have to) work for politics and society but with them.

And last but not least, public participation (in whatever form) is mandatory for a democratic society. Including the citizen, the local farmer or artist, brings new understanding and insight from different perspectives into the decision-making process that goes beyond the "classical" expert knowledge. The crucial factor in this is how roles ("politician", "citizen", "expert") are defined and communicated and it is apparent that a great deal more must be done here, especially in the CCS debate.

\section{References}

1. Baker, F. (1990). Risk communication about environmental hazards. Journal of Public Health (3), p. 341-359.

2. Brzoska, I. (2009). Das ist Wahlbetrug. Berliner Zeitung, 02.11.2009. Retrieved June 4, 2014, from: http:// www.berliner-zeitung.de/archiv/die-linke-haelt-an-der-braunkohle-fest---gegner-der-co2-verpressungfuehlen-sich-hintergangen--das-ist-wahlbetrug-,10810590,10676942.html

3. Bund plant CCS-Gesetz im Miniaturformat (2010). MOZ, 25.03.2010. Retrieved June 2nd, 2014, from: http://www.moz.de/artikel-ansicht/dg/o/1/133404.

4. Bundesregierung (2009). Rede von Bundeskanzlerin Dr. Angela Merkel auf dem Kongress des Bundesverbandes der Energie- und Wasserwirtschaft e.V. (BDEW), Berlin. Retrieved June 7, 2014, from: http://www.bundesregierung.de/Content/DE/Bulletin/200g/06/75-2-bk-bdew.html.

5. Die Vattenfalle (n.d.). Website citizen initiative CO2ntraEndlager. Retrieved June 7, 2014, from: http:// www.co2bombe.de/joomla/index.php/component/content/article/116-co2bombe/topaktuell/784-dievattenfalle.

6. Deutscher Bundestag (2011). Pro und contra unterirdische Kohlendioxidspeicherung. Retrieved June 2nd, 2014, from: $h t t p: / / w w w . b u n d e s t a g . d e / d o k u m e n t e / t e x t a r c h i v / 2011 / 34311885$ kw19_sp_ccs/205276.

7. Fischer, L. (2010). Der CCS-Wahnsinn zerstört unsere Zukunft und die unserer Kinder! Oderbruchpavillon. Retrieved June 5, 2014, from: http://oderbruchpavillon.de/bausteine/initiativen/bi-co2.html.

8. Gesellschaft für Deutsche Sprache (2010). Pressemitteilung vom 17. Dezember 2010: "Wutbürger" zum Wort des Jahres 2010 gewählt. Retrieved June 2nd, 2014, from: http://www.gfds.de/presse/ pressemitteilungen/171210-wort-des-jahres-2010/.

9. Grefe, C., \& Schnabel, U. (2011). Wir müssen zukunftsoffen bleiben. Die Zeit, 24.05.2011, 21/2011. Retrieved June 2nd, 2014, from: http://www.zeit.de/2011/21/Energie-Ethikkommission.

10. Hance, B., Chess, C., \& Sandman, P. (1988). Improving Dialogue with Communities: A Risk Communication 
Manual for Government. Trenton, NJ: Division of Science and Research Risk Communication Unit, New Jersey Department of Environmental Protection.

11. Hintergrund (n.d.). Website citizen initiative CO2ntraEndlager. Retrieved June 4, 2014, from: http://www. cozbombe.de/joomla/index.php/hintergrund.

12. Ickert, J. (Director)(2012). Energieland [Dokumentation]. HFF Konrad Wolf.

13. Jung, A. (2011). Verhängnisvolle Klausel. Der Spiegel, 18.04.2011, 16/2011. Retrieved June 4, 2014, from: http://www.spiegel.de/spiegel/print/d-78076142.html.

14. Knaupp, J. (2010). Am Volk vorbei regiert. Website citizen initiative CO2ntraEndlager. Retrieved June 17, 2014, from: http://www.co2bombe.de/joomla/index.php/offene-briefe/474-co2-speicherung-vattenfallverliert-kampf-um-die-kohle

15. Kreuze warnen vor Kohlendioxid-Risiko (2010). Website citizen initiative CO2ntraEndlager. Retrieved June 3, 2014, from: http://www.co2bombe.de/joomla/index.php/archiv/archiv-medienberichte/488-kreuzewarnen-vor-kohlendioxid-risiko.

16. Kritische Punkte (n.d.). Website citizen initiative CO2ntraEndlager. Retrieved June 6, 2014, from: http:// www.co2bombe.de/joomla/images/stories/co2/punkte.pdf.

17. Kuckshinrichs,W., \& Hake,J.-F.(Eds.)(2012).CO2-Abscheidung,-Speicherung und -Nutzung:Wirtschaftliche, umweltseitige und gesellschaftliche Perspektive. Schriften des Forschungszentrums Jülich, Reihe Energie \& Umwelt, Advances in Systems Analysis 2.

18. König, W. (2013). Die inklusive Teilhabe: Erfahrungen aus der Endlagersuche. In: Töpfer, K., Volkert, D., Mans, U. ( Eds. ). Verändern durch Wissen: Chancen und Herausforderungen demokratischer Beteiligung: von „Stuttgart 21“ bis zur Energiewende, München: oekom verlag, 99-113.

19. Morse, E. (2009). Dealing with information about complex issues. The role of source perception. Universiteit Leiden.

20. Perez-Carmona, A. (2013). Widerstand gegen Infrastrukturprojekte besser verstehen - In:Töpfer, K., Volkert, D., Mans, U. ( Eds. ), Verändern durch Wissen: Chancen und Herausforderungen demokratischer Beteiligung: von „Stuttgart 21“ bis zur Energiewende, München:Oekom-Verlag, 148-158.

21. Pietzner, K., \& Schumann, D. (Hrsg)(2012). Akzeptanzforschung zu CCS in Deutschland: Aktuelle Ergebnisse, Praxisrelevanz, Perspektiven. Oekom-Verlag.

22. Renn, O. (2011). Die Rechnung ohne den Wirt gemacht? CCS im Lichte der Bevölkerung. Universität Stuttgart und DIALOGIK gemeinnützige GmbH. Retrieved June 2nd, 2014, from: https://www.iz-klima.de/w/files/ kongress-2011/110328_ccs-kongress_ortwin-renn.pdf.

23. Renn, O., \& Rohrmann, B. (eds.)(2000). Cross-Cultural Risk Perception. A Survey of Empirical Studies. Dordrecht and Boston.

24. Seidler, C. (2010). CO2-Lager: Angst vor Bürgern blockiert Klimaschutztechnologie. Spiegel Online, 19.11.2010. Retrieved June 4, 2014, from:http://www.spiegel.de/wissenschaft/technik/co2-lager-angst-vorbuergern-blockiert-klimaschutztechnik-a-729915.html.

25. Schramm, S. (2010). Das zweite Wendland. Die Zeit, Ausgabe 47/2010, WISSEN. 
26. Schröder, D. (2010). CO2-Speicherung: Wir wollen nicht das CO2-Klo Deutschlands werden. Spiegel Online, 05.05.2010. Retrieved June 4, 2014, from: http://www.spiegel.de/wissenschaft/natur/co2-speicherung-wirwollen-nicht-das-co2-klo-deutschlands-werden-a-693122-2.html.

27. Sorge, N.-V. (2011). Vattenfall Europe: Vom Heilsbringer zum Prügelknaben. Manager-Magazin, 09.05.2011. Retrieved June 4, 2014, from: http://www.manager-magazin.de/unternehmen/energie/a-760680.html.

28. SPD Brandenburg \& Die Linke Brandenburg (2009). Gemeinsinn und Erneuerung; Ein Brandenburg für alle. Koalitionsvertrag zwischen SPD Brandenburg und Die Linke Brandenburg für die 5. Wahlperiode des Brandenburger Landtages, Potsdam.

29. Über uns (n.d.). Website citizen initiative CO2-Endlager stoppen. Retrieved June 17, 2014, from: http://www. kein-co2-endlager.de/index.php?option $=$ com_content\&view $=$ article\&id $=75 \&$ Itemid $=61$.

30. Vattenfall-Newsletter (2009). Bridging to the future. Newsletter on Carbon Capture \& Storage at Vattenfall, No. 14.

31. Vattenfall-Newsletter (2010). Bridging to the future. Newsletter on Carbon Capture \& Storage at Vattenfall, No. 15 . 